\title{
IAMJ
}

INTERNATIONAL

AYURVEDIC

MEDICAL JOURNAL

\section{NEW PERSPECTIVE OF AJA KSHEERA W.S.R TO VRUSHYA ACTIVITY - A REVIEW}

\author{
$\underline{\text { Manju Prasad M. K }}^{1^{*}}$, $\underline{\text { Mamatha Sri. }}^{2}$, $\underline{\text { Nagendra Chary. }}^{3}$ \\ ${ }^{* 1}$ PG Scholar, ${ }^{2}$ Associate Professor, ${ }^{3} \mathrm{Ph}$. D Scholar, \\ Department of Dravyaguna, Government Ayurveda Medical College and Hospital, Bengaluru, Karnataka, India
}

Corresponding Author: manjuprasadmk@gmail.com

\section{https://doi.org/10.46607/iamj14p6012021}

(Published online: November 2021)

Open Access

(C) International Ayurvedic Medical Journal, India 2021

Article Received: 01/10/2021 - Peer Reviewed: 07/10/2021 - Accepted for Publication: 08/10/2021

\begin{abstract}
Shukra dhatu is meant for procreation, its Kshaya (diminution) causes Male Infertility. Shukra dhatu is formed by the transformation of Aahara rasa (food) with the help of Agni (digestive fire). Aahara is one of three important sub pillars which supports life. Ksheera is Satmya (wholesome), and it is Dhatu Vardhaka (nourishes the body tissues), Rasayana (rejuvenation), Vajikarana / Vrushya (aphrodisiac), generally indicated in Shukra Doshas (seminal disorders). Aja Ksheera (Goat milk) attributes Laghu (light), Balya guna (Strength promotor) along with Deepana (kindles the digestive fire), Grahi Karma (absorptive) praised for its Sarva-Vyadi Hara (cures all ailments) and Shukrala karma (spermatogenic measure). It is easily digestible when compared to Goksheera (cow milk) and it is a good source of essential fatty acids such as linoleic, vitamin A, and trace elements like Zinc, Mg which are essential factors for the production of sperm and male hormone. Formulations of Aja Ksheeera namely Chagaladya ghrutha, Tilagokshuradi yoga possess Vrushya property and are indicated in Nastashukra (diminution of semen), Shukra Nisarana, Shanda (impotency) conditions. The Guna Karma of Aja Ksheera along with its rich nutritive value supports the spermatogenesis thus it can be considered in the treatment of Shukrakshaya as Aahara as well Aushadha.
\end{abstract}

Keywords: Aja Ksheera, Goat Milk, Vrushya, Spermatogenic, Aphrodisiac 


\section{INTRODUCTION}

Food is one of the three sub pillars of life, other two being Nidra (Sleep) and Abhramacharya (Regulated sexual conduct $)^{[1]}$ Alteration of food habits and change in lifestyle causes various sexual dysfunctions and impaired reproductive health status. ${ }^{[2]}$ Proper nutrition plays a very important role in the maintenance of Reproductive Health. To maintain the strength of Shukra dhatu there arises a need for usage of various food articles having Vrushya properties in regular diet. Acharyas of Ayurveda have explained a unique concept of food, its classification, usage and therapeutic indications. Drava varga (Liquid portion) \& Annapaanavarga (Solid portion) are the important classification of foods. Ksheera (Milk) is one among dravadravya which is given utmost importance. Eight types of milk, their properties and therapeutic indications have been explained. Acharya Susrutha opines that Ksheera is Jaatisathmyatha i.e compatible from birth. Generally, it is Guru (heavy for digestion), Snigdha (unctuous), Madhura rasa (sweet), Sheeta veerya (cold in potency), Madhura vipaka, Rasayana (rejuvenation), Dhatu Vardhaka (nourishes the body tissues), Vrushya, Vajikarana (aphrodisiac) and it is praised for its Sadhya Shukrakara (instantly increases shukra) properties commonly used in diet and for medicinal purpose. ${ }^{[3-5]}$

Among eight types of Ksheera, Aja ksheera (goat milk) has similar properties to Go-Ksheera with special attributes with Laghu, Snigdha, Sheetaguna, Shukrala karma and also indicated in many Vrushya yogas namely Chagaladhya Ghrita, Tilagoshuradi churna, it is used as an ingredient, processing agent and vehicle (Anupana). It is easily digestible when compared to Goksheera and it is the source of essential fatty acids such as linoleic, vitamin A, trace elements like zinc, $\mathrm{Mg}$ which are essential factors for the production of sperm and male hormones. ${ }^{[6]}$ Thus, an attempt is made to review Ajaksheera for its Vrushya karma which is an Aaharadravya and also loaded with Aoushadha Guna.

\section{Objective}

To establish the Vrushya karma of Aja ksheera.

\section{Materials and Methods}

Literary review of classical texts namely Charaka $\mathrm{Sa}$ mitha, Sushrutha Samitha, Astanga Hrudaya, Bhavaprakasha Nighantu, Kaiyadeva Nighantu and Research update.

\section{General Properties of Milk.}

"Ksheeram Jeevaniyanam" milk is the best substance for promoting life. ${ }^{[7]}$ Milk is a nutrient-rich liquid food, and it is part and parcel of a regular diet. Acharyas elaborate that milk has Madhura rasa (sweet), Snigdha guna (unctuous), Sheetaveerya (cold in potency), Stanya (lactogenic), Preenana (refreshing), Brimhana (nourishing), Vayastapana (maintenance of youth), Rasayana (rejuvenation) Vrushya (libidinal stimulant-aphrodisiac), Vajikarana (aphrodisiac), SadyaShukrakara (instantly nourishes Shukra) Balya (strength promotor), Ojasya (improves the vital dhatu Ojas), Manaskaram (useful for mental faculties), JatiSatmyaiya: it is wholesome for all living beings and PathyaTama (best among healthy food) $\cdot{ }^{[8-11]}$ Eight types of milk have been explained based on the source, they are milk of cow, buffalo, goat, sheep, camel, elephant, mare and woman (human breast milk).

Table 1: Guna Karma of AstaKsheera (Eight types of milk) ${ }^{[12-15]}$

\begin{tabular}{|l|l|l|l|}
\hline SI no & Types Of Milk & Properties & Pharmacological Activities \\
\hline 1 & $\begin{array}{l}\text { Go-Ksheera } \\
\text { (Cow's Milk) }\end{array}$ & $\begin{array}{l}\text { Guru, Sheeta, Madhura } \\
\text { (Buffalo milk) }\end{array}$ & Jeevaniya, Rasayana, Balya \\
\hline 2 & $\begin{array}{l}\text { Aja Ksheera } \\
\text { (Goat milk) }\end{array}$ & $\begin{array}{l}\text { Madhura, Laghu, } \\
\text { Sheeta, Mrudu, Balya }\end{array}$ & Sarvavyadi Hara, Shukrala \\
\hline 4 & $\begin{array}{l}\text { Avi ksheera } \\
\text { (Sheep milk) }\end{array}$ & $\begin{array}{l}\text { Snigdha, } \\
\text { Madhura }\end{array}$ \\
\hline
\end{tabular}




\begin{tabular}{|l|l|l|l|}
\hline 5 & $\begin{array}{l}\text { Oshtra Ksheera } \\
\text { (Camel milk) }\end{array}$ & $\begin{array}{l}\text { Rooksha, Laghu (Light), } \\
\text { Slightly Salty }\end{array}$ & Deepana, Kaphavata hara, Visha hara \\
\hline 6 & $\begin{array}{l}\text { Hasti Ksheera } \\
\text { (Elephant milk) }\end{array}$ & Guru, Snigdha & $\begin{array}{l}\text { Balya (Strengthening), Stairya Karam (Stabilizing), Vrushya } \\
\text { (Aphrodisiac), Chakshusya (Good for Eyes). }\end{array}$ \\
\hline 7 & $\begin{array}{l}\text { Eka Shapa } \\
\text { Ksheera } \\
\text { (Milk of one hoof } \\
\text { animal) }\end{array}$ & $\begin{array}{l}\text { Ushna, Amla-Lavana, } \\
\text { Rooksha }\end{array}$ & $\begin{array}{l}\text { Stairyakaram (stabilizing), Balya (strength promoting), Shakhav- } \\
\text { ata hara (alleviates vatika diseases of extremities) }\end{array}$ \\
\hline 8 & $\begin{array}{l}\text { Stree Ksheera } \\
\text { (Woman breast } \\
\text { milk) }\end{array}$ & Kashaya Madhura Rasa & $\begin{array}{l}\text { Jeevanam (Invigorating), Brimhana (Nourishing), Sathmya } \\
\text { (Wholesome) }\end{array}$ \\
\hline
\end{tabular}

\section{Aja Ksheera}

Aja (Goat) drinks less water, usually feeds on plants' rich in katu - tikta rasa (pungent -bitter taste), does more activities and possess lean body. Goat milk is attributed with Kashaya (astringent) Madhura rasa (sweet), and Sheetaveerya (cold in potency), Laghu guna (light), Mrudu guna, Deepana (stimulates digestive fire), Sangrahi (absorptive), Balya (Strength pro- motor) Tridosha hara (alleviates all three doshas), Sarvavyadhi hara Karmas. Acharya Kaiyadeva added Shukrala karma along with the above said gunakarma. ${ }^{[15,16]}$

Acharya Sushruta states goat milk has similar properties as that of cow milk. It is indicated in various conditions like Raktapitta (Bleeding disorders), Kshaya (emaciation), Shosha (emaciation) and Kshataksheena. ${ }^{[17]}$

Table 2: Guna Karma of Aja Ksheera According Different Acharyas ${ }^{[15-18]}$

\begin{tabular}{|c|c|c|c|c|c|c|}
\hline Sl.no & $\begin{array}{l}\text { Charac- } \\
\text { ters }\end{array}$ & Charaka & Sushrutha & Vagbhata & $\begin{array}{l}\text { Kaiyadeva } \\
\text { Nigantu }\end{array}$ & $\begin{array}{l}\text { Bhavaprakasha } \\
\text { Nigantu }\end{array}$ \\
\hline 1 & Rasa & $\begin{array}{l}\text { Kashaya (Astringent) } \\
\text { Madhura (Sweet) }\end{array}$ & - & - & Madhura (sweet) & $\begin{array}{l}\text { Kashaya (Astrin- } \\
\text { gent) } \\
\text { Madhura (Sweet) }\end{array}$ \\
\hline 2 & Guna & Laghu (Light) & Laghu (light) & Laghu (light) & $\begin{array}{l}\text { Laghu, Snigda } \\
\text { Mrudu }\end{array}$ & Laghu(light) \\
\hline 3 & Veerya & Sheeta (Cold) & - & - & Sheetala (cold) & Sheeta (cold) \\
\hline 4 & Karma & Grahi (absorptive) & - & - & $\begin{array}{l}\text { Sangrahai, Deepana } \\
\text { Balya, Shukrala }\end{array}$ & Grahi (absorptive) \\
\hline
\end{tabular}

\section{Nutritional value of Goat milk}

According to the Journal of American Medicine, "Goat milk is the most complete food known." It contains vitamins, minerals, electrolytes, trace elements, enzymes, protein, and fatty acids that are utilized by the human body with ease. Our body can digest goat milk in just 20 minutes while it takes2-3 hours to digest cow milk. ${ }^{[19]}$ Biochemically goat milk has greater concentrations of essential fatty acids such as linoleic and arachidonic acid, Vitamin B3, B6, Vitamin A, and Potassium (K) than cow milk. One cup of goat milk supplies $35 \%$ of our daily need of calcium, $20 \%$ of daily need of B2. A high level of potassium causes goat milk to react in an alkaline way within the body whereas cow milk reacts in an acidic way due to lees amount of potassium. ${ }^{[19]}$ The Importance of goat milk is that the oligosaccharide profile of goat milk is most similar to that of human milk and the goat milk oligosaccharides could be included in infant formulas to improve the nutrition of infants. ${ }^{[20]}$ Goat milk has better digestibility and absorption. Goat milk is much higher in short-chain fatty acids and medium-chain fatty acids 
and these short-chain fatty acids and medium-chain fatty acids have a larger surface-to-volume ratio and are better digested and absorbed than the long-chain fatty acids prevalent in cow milk. ${ }^{[21]}$

Mineral salt: The milk contains major and traces minerals including $\mathrm{Ca}, \mathrm{Na}, \mathrm{Mg}, \mathrm{P}, \mathrm{K}$ and $\mathrm{Zn}, \mathrm{Mn}, \mathrm{Se}, \mathrm{Co}$,
$\mathrm{Cu}, \mathrm{Fe}$. For instance, milk is a good source of calcium, containing approximately $13 \%$ more calcium per serving than cow's milk, and making it one of the predominant natural minerals in milk and containing about $134 \%$ more potassium element. ${ }^{[22]}$

Table 3: Basic Nutrients, Minerals \& Vitamins Concentrations (per 100g) for cow and goat milk ${ }^{[23,24]}$

\begin{tabular}{|l|l|l|}
\hline \multicolumn{1}{|c|}{ Constituents } & Cow milk & Goat milk \\
\hline Protein $(\mathrm{g})$ & 3.3 & 3.5 \\
\hline Fat $(\mathrm{g})$ & 3.6 & 3.8 \\
\hline Lactose $(\mathrm{g})$ & 4.6 & 4.1 \\
\hline Calories (cal) & 69 & 70 \\
\hline Total solids & 12.3 & 12.2 \\
\hline Ash (g) & 0.7 & 0.8 \\
\hline Zinc "Zn" (mg) & 0.53 & 0.56 \\
\hline Magnesium "Mg" (mg) & 119 & 141 \\
\hline Selenium "Se" (mg) & 0.96 & 1.33 \\
\hline Potassium "K" (mg) & 152 & 181 \\
\hline Vitamin A(I.U.) & 126 & 185 \\
\hline Vitamin C (mg) & 0.94 & 1.29 \\
\hline
\end{tabular}

\section{Vrushya Karma}

The term Vrushya indicates the substances by use of which a person becomes capable to act sexually like a bull. Acharya Charaka states Vrushya as one of the synonyms for Vajikarana. ${ }^{[25]}$ Vrushya and Vajikarana terms are both used for Shukrala karma. ${ }^{[26-28]}$ Vrushya has been described as 'Shukra Janakam' and Sukravriddhikara ${ }^{[29]}$ means which increases the quantity and quality of Shukra in the human body thus improving seminal parameters. Chakrapani described the term Vrushya as the substances which either increase the production of Shukra or facilitate ejaculation of semen to the exterior of the body. ${ }^{[30]}$ The dravyas are Madhura (sweet), Snigdha (unctuous), Jeevaneeya (promoter of life), Brihmana (nourishing), Guru (heavy to digest), which can cause Harsha (excitement) can be called Vrushya. ${ }^{[31]}$

Table 4: Yogas indicated for Vrushya that consist of goat milk as one of the ingredients.

\begin{tabular}{|l|l|l|l|}
\hline Si. no & Formulations & Reference & Indication/ Karma \\
\hline 1 & Vrushyatama Uttara basti & Cha Sam Siddisthana 12/16 & Vrushya, Bala, Varna janana \\
\hline 2 & Tilagoskhurachoorna & Bhai ratnavali 75/11 & Shanda (Impotency) \\
\hline 3 & Chagaladhyagritha & Bhai ratnavali 15/188-194 & Dvajabhanga (erectile dysfunction) \\
\hline 4 & Chagaladhighrita & Bhai ratnavali 74/298-321 & $\begin{array}{l}\text { Nasta Shukra (diminution of semen) } \\
\text { Shukranisarana, Ratishaktivardaka (increases libido) }\end{array}$ \\
\hline 5 & Drakshadhi Kashaya & Sahasrayoga & Rajayakshma \\
\hline
\end{tabular}

\section{Nutrition and reproductive health}

During the initiation of spermatogenesis, folate and Vit B12 are especially critical due to their significant role in RNA and DNA synthesis. Selenium and zinc are important co-factors that incorporate enzymes in the process of polymerization and transcription. GPx 4 is an essential element that works with selenium to protect vulnerable germ cells from oxidative stress. 
Vitamin A plays a role in regulating spermatogenesis, particularly during the starting phase. Both vitamin B9 and vitamin E deficiency negatively impact sperm production. Vitamin C and Vitamin E both protect sperm from oxidative stress. These nutritional elements also play crucial roles in promoting sperm motility, semen quality and Sertoli cell , Leydig cell development. ${ }^{[32]}$

Table 5: Nutrients and their action on sexual health. ${ }^{[33]}$

\begin{tabular}{|c|c|c|}
\hline SLNO & NUTRIENT & ACTION ON SEXUAL HEALTH \\
\hline \multicolumn{3}{|c|}{ MACRONUTRIENTS } \\
\hline 1. & Carbohydrate & Increases libido, fructose increases sperm mobility. \\
\hline 2. & Protein & Amino acids can regulate sex hormone levels. \\
\hline 3. & Fat & Fatty acids such as omega- 3 help us keep calm and promote a healthy mood. \\
\hline \multicolumn{3}{|c|}{ VITAMINS } \\
\hline 4. & A & $\begin{array}{l}\text { Essential for the production of male and female sex hormones, for the normal reproductive cycle } \\
\text { in a woman. }\end{array}$ \\
\hline 5. & $\mathrm{C}$ & $\begin{array}{l}\text { Synthesis of hormones like androgen, estrogen, progesterone, strengthen the immune system, pro- } \\
\text { tect against day-to-day stress. }\end{array}$ \\
\hline 6. & $\mathrm{D}$ & Erection of penis, Maintain orgasm and libido. \\
\hline 7. & $\mathrm{E}$ & $\begin{array}{l}\text { Known as a sex vitamin, it enhances sexual arousal and behaviour, is a powerful antioxidant and } \\
\text { anti-ageing. }\end{array}$ \\
\hline 8. & B1 & Maintain energy and sexual drive. \\
\hline 9. & B3 & Enhances sexual flush increases blood flow to genitals and intensify orgasm. \\
\hline 10. & B6 & $\begin{array}{l}\text { Libido enhancer controls elevated prolactin. It also aids estrogen, progesterone function, produc- } \\
\text { tion of red blood cells, serotonin, dopamine and is good for increasing sperm count. }\end{array}$ \\
\hline 11. & B9 & It can increase sperm count. \\
\hline 12. & B12 & Heighten sex drive, enhance penile erection, stimulate secretion of histamine needed for orgasm. \\
\hline \multicolumn{3}{|c|}{ MINERALS } \\
\hline 13. & $\mathrm{Mg}$ & Improve libido and sexual performance also increase sexual drive. \\
\hline 14. & Selenium & Increase sperm production. \\
\hline 15. & Zinc & Production of testosterone \& sperm, prostate health, regulate the production of semen. \\
\hline 16. & Iron & $\begin{array}{l}\text { Iron is needed to get oxygen to your cells if low iron in the body will show the symptom of low } \\
\text { sexual drive. }\end{array}$ \\
\hline 17. & Calcium & $\begin{array}{l}\text { It is an essential nutrient that establishes the link between hormonal glands and the brain. Defi- } \\
\text { ciency results in low sexual drive. }\end{array}$ \\
\hline 18. & Manganese & Need for build up a healthy reproductive system. \\
\hline
\end{tabular}

\section{DISCUSSION}

Acharya Charaka quoted Aja ksheera in the context of Agra Prakarana stating it as the best drug for its Sathmya, Sangrahika Guna indicating in Shosha and Raktapitta $^{[34]}$. According to modern science, malnutrition causes Hypogonadism and decreased function of Leydig cells due to reduced response of the male accessory organs to testosterone stimulation. Vit-A deficiency causes testicular atrophy and reduced sperm count. ${ }^{[35]}$ Foods that are rich in vitamin A, C, B3, B6,
B12, B9, E and minerals like $\mathrm{Mg}, \mathrm{Se}, \mathrm{Zn}$ have significant action on various stages of sexual activity. ${ }^{[36]}$ Use of Vajikaranayogas, Raktapitta Hara Yogas (formulations for the bleeding disorder), Yonivyapadchikista (treatment used in gynecological disorders) are the line of management of Shukra doshas and acharya Charaka suggest the use of ghee, milk, shaali etc. as diet. ${ }^{[37]}$

Ksheera generally possesses Vrushya properties. Aja Ksheera is best Rakta Pitta Prashamaka consist similar properties of cow milk with potential guna, karma 
as explained in table 1, table 2 attributed with Shukrala karma and Sarva Vyadhi hara karma. The Laghu Guna of Aja ksheera helps for its easy digestion, Shukra is formed by Aahara rasa with the help of the proper function of Dhatvagni. Deepana, Grahi guna of Ajaksheera stimulates the digestive fire which helps in treating the patient of Shukra dosha with Mandagni correcting the imbalance of Dhathvagni thereby enhancing the production of Sthanika and Sarvadahika Shukra. Premature ejaculation is one of the seminal disorders, where Shukra Stambana karma is needed. The Kashaya rasa and Sheeta Veerya qualities of Aja ksheera helps to decrease the Chalaguna, thus it can be considered for Shukra Stambana activity. Acharya Kaiyadeva mentioned Aja ksheera as Shukrala. Aja ksheera as an ingredient and as a processing agent mentioned in various Vrushya yogas and are indicated in Shanda (Impotent). Formulation of Ajaksheera (Table 4) namely Chagaladyaghritha, Tilagokshuradi yoga possesses the Vrushya properties and is commonly indicated in Nasta Shukra, Shukra Nisaarana, Dwajabanga (erectile dysfunction) etc. Aja Ksheera is attributed with essential nutrients and pharmacological activities required for Vrushya activity.

\section{CONCLUSION}

- Ajaksheera possesses Vrushya activity, does both spermatogenesis and improves sexual health.

- It can be used as an ingredient and processing agent in the preparation of Vrushya formulations.

- It can be used as a Vehicle (Anupana) in the administration of Vrushya yogas and as a Diet in Shukradosha.

\section{REFERENCES}

1. Acharya Vagbhata, Astanga hrdaya (Sutra sthana 7th chapter sloka no 52) edited by Pt. Hari Sadasiva Sastri Paradakara Bhisagacarya, Varanasi Chaukhamba Surbharati Prakashan, year of publication 2014, page no 140

2. Athira KS, Tripathy TB, Sukumar BS. Ayurvedic food supplements for sexual health: a review article. Int $\mathbf{J}$ Health Sci Res. 2019; 9(5):347-355

3. Acharya Vagbhata, Astanga hrdaya (Sutra sthana 5th chapter sloka no 20) edited by Pt. Hari Sadasiva Sastri Paradakara Bhisagacarya, Varanasi Chaukhamba
Surbharati Prakashan, year of publication 2014, page no 67

4. Acharya Sushruta, Sushruta Samitha (Sutra Sthana 45th chapter shloka no 49) edited by Vaidya Jadavji Trikarmji Acharya and Narayan Ram Acharya Kavyatirtha, Varanasi Chaukhamba Surbharati Prakashan, year of publication 2014, page no 200

5. Prof Krishna Chand Chunekar. Bhava prakasha Nighantu. (Dugdha varga sloka no 1-2) Edited by Dr G Pandey,28th edition revised. Varanasi. Published Chaukhambha Bharati Academy, year of publication 2020, page no 745

6. Ashish Kumar, Ambika Sharma, Nutritional and Medicinal Superiority of Goat Milk over Cow Milk in Infants, International Journal of Pediatric Nursing, Volume 2 Number 1 / January - April 2016 DOI: 10.21088/ijpen.2454.9126.2116.

7. Acharya Charaka, Charaka Samitha (Sutrasthana 25th Chapter, Shloka No-40) edited by Vaidya Yadavji Trikarmji Acharya, Varanasi Chaukhamba Surbharati Prakashan, year of publication 2014, page no 353

8. Acharya Charaka, Charaka Samitha (Sutrasthana 1st Chapter, Shloka No- 105-113) edited by Vaidya Yadavji Trikarmji Acharya, Varanasi Chaukhamba Surbharati Prakashan, year of publication 2014, page no37

9. Acharya Sushruta, Sushruta Samitha (Sutra Sthana 45th chapter shloka no 48-49) edited by Vaidya Jadavji Trikarmji Acharya and Narayan Ram Acharya Kavyatirtha, Varanasi Chaukhamba Surbharati Prakashan, year of publication 2014, page no 200

10. Acharya Vagbhata, Astanga hrdaya (Sutra sthana 5th chapter sloka no 20) edited by Pt. Hari Sadasiva Sastri Paradakara Bhisagacarya, Varanasi Chaukhamba Surbharati Prakashan, year of publication 2014, page no 67

11. Prof Krishna Chand Chunekar. Bhava prakasha Nighantu. (Dugdha varga sloka no 1-2) Edited by Dr G Pandey,28th edition revised. Varanasi. Published Chaukhambha Bharati Academy, year of publication 2020, page no 745

12. Acharya Charaka, Charaka Samitha (Sutrasthana 27th Chapter, Shloka No-217-224) edited by Vaidya Yadavji Trikarmji Acharya, Varanasi Chaukhamba Surbharati Prakashan, year of publication 2014, page no 439

13. Acharya Sushruta, Sushruta Samitha (Sutra Sthana 45th chapter shloka no 50-58) edited by Vaidya Jadavji 
Trikarmji Acharya and Narayan Ram Acharya Kavyatirtha, Varanasi Chaukhamba Surbharati Prakashan, year of publication 2014, page no 201

14. Acharya Vagbhata, Astanga hrdaya (Sutra sthana 5th chapter sloka no 21-27) edited by Pt. Hari Sadasiva Sastri Paradakara Bhisagacarya, Varanasi Chaukhamba Surbharati Prakashan, year of publication 2014, page no 140

15. Acharya Kaiyadeva, Kaiyadeva Nighantu, (Dugdha Varga, Shloka No- 133-135) redacted by Sharma P.V., 1 st edition, New-Delhi, Chaukhambha publications, year of publication1979, PP No- 343.

16. Prof Krishna Chand Chunekar. Bhava prakasha Nighantu. (Dugdha varga sloka no 14) Edited by Dr G Pandey,28th edition revised. Varanasi. Published Chaukhambha Bharati Academy, year of publication 2020, page no 746

17. Acharya Sushruta, Sushruta Samitha (Sutra Sthana 45th chapter shloka no 51-52) edited by Vaidya Jadavji Trikarmji Acharya and Narayan Ram Acharya Kavyatirtha, Varanasi Chaukhamba Surbharati Prakashan, year of publication 2014, page no 202

18. Acharya Charaka, Charaka Samitha (Sutrasthana 27th Chapter, Shloka No-222) edited by Vaidya Yadavji Trikarmji Acharya, Varanasi Chaukhamba Surbharati Prakashan, year of publication 2014, page no 439

19. Ashish Kumar, Ambika Sharma, Nutritional and Medicinal Superiority of Goat Milk over Cow Milk in Infants, International Journal of Pediatric Nursing, Volume 2 Number 1 / January - April 2016 DOI: 10.21088/ijpen.2454.9126.2116.5

20. Daddaoua A, Puerta V, Requena P, Martinez-Ferez A, Guadix E, Sanchez de Medina F, Zarzuelo A, Suarez MD, Boza JJ, Martinez-Augustin O. 2006. Goat Milk Oligosaccharides Are Anti-Inflammatory in Rats with Hapten-Induced Colitis. J Nutr. 136: 672-676.

21. Razafindrakoto O, Ravelomanana N, Rasolofo A, Rakotoarimanana RD, Gourgue P, Coquin P, Briend A. 1994. Goat's milk as a substitute for cow's milk in undernourished children: a randomized double-blind clinical trial. Paediatrics. 94(1):65

22. Haenlein GFW (2002) Composition of goat milk and factors affecting it. Small Rumi Res 51: 155-63.

23. Harden CJ and Hepburn NJ, The benefits of consuming goat's milk, 2011

24. Haenlein, G. F. W. and Caccese, R. Goat Milk versus Cow Milk. Extension Goat Handbook; USDA Publ.: Washington, DC 1984; p. 1.-E-1
25. Acharya Charaka, Charaka Samitha (Chikitsasthana 2nd Chapter 4th pada, Shloka No-5-6) edited by Vaidya Yadavji Trikarmji Acharya, Varanasi Chaukhamba Surbharati Prakashan, year of publication 2014, page no 394

26. Acharya Sushruta, Sushruta Samitha edited by Vaidya Jadavji Trikarmji Acharya and Narayan Ram Acharya Kavyatirtha, Varanasi Chaukhamba Surbharati Prakashan, year of publication 2014, page no 207

27. Acharya Sushruta, Sushruta Samitha edited by Vaidya Jadavji Trikarmji Acharya and Narayan Ram Acharya Kavyatirtha, Varanasi Chaukhamba Surbharati Prakashan, year of publication 2014, page no 223.

28. Shailaja Srivastava, Sharngadharasamhita (Purva khanda 4/13). Varanasi Chaukhambha Orientalia. year of publication 2003-page no.33.

29. Bhavprakash of Bhavmisra, edited Vidyotini Hindi Commentary by Brahmasankar M, Purvakhanda,3/ 191, Varanasi Chaukhamba Sanskrita Bhawan, reprint edition; 2013. Page no. 60.

30. Acharya Charaka, Charaka Samitha (Chikitsasthana 2nd Chapter 4th pada, Shloka No-51) edited by Vaidya Yadavji Trikarmji Acharya, Varanasi Chaukhamba Surbharati Prakashan, year of publication 2014, page no 397

31. Acharya Charaka, Charaka Samitha (Chikitsasthana 2nd Chapter 4th pada, Shloka No-36) edited by Vaidya Yadavji Trikarmji Acharya, Varanasi Chaukhamba Surbharati Prakashan, year of publication 2014, page no 397

32. Yunsang Cheah, Wanxi Yang, Functions of essential nutrition for high-quality spermatogenesis, Advances in Bioscience and Biotechnology 2 (2011) 182-197. doi:10.4236/abb.2011.24029

33. Athira KS, Tripathy TB, Sukumar BS. Ayurvedic food supplements for sexual health: a review article. Int $\mathbf{J}$ Health Sci Res. 2019; 9(5):347-355

34. Acharya Charaka, Charaka Samitha (sutra sthana $25^{\text {th }}$ Chapter Shloka No-40) edited by Vaidya Yadavji Trikarmji Acharya, Varanasi Chaukhamba Surbharati Prakashan, year of publication 2014, page no 132

35. Dr Kumar Mahendra*, Dr Tripathy Sasmita and Dr Sharma Anita THE ROLE OF VRUSHYA YAWAGU IN SHUKRAKSHAYA (OLIGOSPERMIA) ww.wjpr.net | Vol 10, Volume 10, Issue 4, 938-942.

36. Athira KS, Tripathy TB, Sukumar BS. Ayurvedic food supplements for sexual health: a review article. Int $\mathrm{J}$ Health Sci Res. 2019; 9(5):347-355 
37. Acharya Charaka, Charaka Samitha (Chikistasthana 30th Chapter Shloka No-146-152) edited by Vaidya Yadavji Trikarmji Acharya, Varanasi Chaukhamba Surbharati Prakashan, year of publication 2014, page no 640

\section{Source of Support: Nil Conflict of Interest: None Declared}

How to cite this URL: Manju Prasad M. K et al: New Perspective Of Aja Ksheera W.S.R To Vrushya Activity - A Review. International Ayurvedic Medical Journal \{online\} 2021 \{cited November 2021\} Available from: http://www.iamj.in/posts/images/upload/3246_3253.pdf 